\title{
PLATES AND MAPS
}

\section{Plates}

All photographs are by the author unless otherwise stated.

1. Temple of Venus Genetrix, Rome.

2. Tomb of Caecilia Metella, Via Appia, Rome.

3. Cleopatra VII and Caesarion, Dendara, Egypt.

4. Pompeii lovers, British Museum, London.

5. Theatre of Marcellus, Rome.

6. Porticus of Octavia, Rome.

7. Ara Pacis, Museo dell'Ara Pacis, Rome.

8. Agrippa and Julia, Ara Pacis, Museo dell'Ara Pacis, Rome.

9. Bust of Livia, British Museum, London.

10. Posthumous bust of Livia as the goddess Ceres, British Museum, London.

11. Clay oil lamp with a bust of Livia, British Museum, London.

12. Building of Eumachia, Pompeii.

13. The Mausoleum of Augustus, Rome.

14. Dedication to the Deified Augusta (Livia), Herculaneum, Museo Archeologico Nazionale, Naples.

15. Porticus of Livia, Marble Plan of Rome, Museo dei Fori Imperiali, Rome. 
16. Inscription of Lucius Caesar, Porticus of Gaius and Lucius, Rome.

17. Temple of Vesta, Roman Forum.

18. The Roman Forum.

19. Tombstone of Agrippina the Elder, Museo Capitolini, Rome.

20. Sestertius of Agrippina the Elder. Private collection.

21. Bronze coin of Messalina. Classical Numismatic Group, www.cngcoins. com.

22. Cistophoric tetradrachm of Claudius and Agrippina. Private collection.

23. The Gemma Claudia, Kunsthistorisches Museum Vienna. Photo and copyright: Gryffindor.

24. Agrippina crowns Nero, Aphrodisias, Turkey. Photo and copyright: Carole Raddato.

25. Nero's Golden House, Rome.

26. Tetradrachm of Nero and Poppaea. Private collection.

27. View of Oplontis.

28. Sestertius of the Temple of the Deified Augustus and Livia. Private collection.

29. The Severan Women. Private collection.

30. Julia Domna and Septimius Severus on the Arch of the Moneychangers (Porta Argentarii), Rome.

31. Sestertius of Julia Mamaea. Private collection.

32. Julio-Claudian dynastic relief, Ravenna, Museo Nazionale di Ravenna. Photo and copyright: John Pollini.

\section{Maps}

1. Rome, showing the main locations mentioned in the text. xvi

2. Roman Italy, showing the main places mentioned in the text. xvii

3. The Roman Empire, showing the main places mentioned xviii in the text. 